\title{
PENGARUH KEMAMPUAN INTELEKTUAL DAN PROMOSI JABATAN TERHADAP KEPUASAN KERJA AGEN ASURANSI PADA PT PRUDENTIAL LIFE ASSURANCE CABANG PRUAINI PS8 PEMATANGSIANTAR
}

\author{
Oleh: \\ Jhon Hendry Siregar \\ S1 Manajemen \\ Darwin Lie, Efendi, Nana TriapnitaNainggolan
}

\begin{abstract}
Abstrak
Hasil penelitian ini dapat disimpulkan sebagai berikut: 1. Kemampuan intelektual, promosi jabatan, dan kepuasan kerja sudah baik. 2. Hasil analisis regresi adalah $\hat{Y}=10,850+0,494 X_{1}+$ $0,418 \mathrm{X}_{2}$, artinya terdapat pengaruh positif antara kemampuan intelektual, dan promosi jabatan terhadap kepuasan kerja pada agen asuransi PT Prudential Life Assurance Cabang Pruaini Agency PS8 Pematangsiantar. 3. Hasil analisis koefisien korelasi diperoleh nilai $r=0,761$, artinya terdapat hubungan yang kuat dan positif antara kemampuan intelektual dan promosi jabatan dengan kepuasan kerja agen asuransi. Nilai determinasi $=0,579$ artinya tinggi rendahnya kepuasan kerja agen asuransi sebesar 57,9\% dapat dijelaskan oleh kemampuan intelektual dan promosi jabatan.

Adapun saran dari hasil penelitian ini adalah: 1. Untuk meningkatkan kemampuan intelektual agen asuransi harus lebih serius lagi memahami pelatihan, monday morning motivation (M3), business opportunity product $(B O P)$ tentang asuransi dan produk-produk baru asuransi. 2. Untuk lebih meningkatkan promosi jabatan sebaiknya agen asuransi lebih serius lagi mengikuti seminar, pelatihan, menawarkan produk asuransi dengan berbagai inovasi sehingga calon nasabah tertarik untuk memiliki polis asuransi dengan demikian target produksi tercapai berdampak pada pengoptimalan kepuasan kerja agen asuransi.
\end{abstract}

Kata Kunci: Kemampuan Intelektual, Promosi Jabatan, dan KepuasanKerja.

\section{Abstract}

The results of this study can be summarized as follows: 1. The intellectual abilities, performance promotion and the performance of insurance agents is excellent. 2. The results of regression analysis is $\hat{Y}=10,850+0,494 X_{1}+0,418 X_{2}$, means that intellectual abilities and performance promotion has a positive effect to job satisfaction insurance agents. 3 . The results of the analysis correlations is $r=0,761$, means that there is moderately high and positive between intellectual abilities, performance promotion and job satisfaction insurance agents. The results of determination is $r$ square $=0,579$, means that the level of job satisfaction insurance agents can be explained by intellectual abilities and performance promotion as big as 57,9\%.

As for the suggestion from the results of this research are: 1 . To enchance the intellectual abilities more seriously insurance agent to understand the training, monday morning motivation $(M 3)$, business opportunity product (BOP) about insurance and understand the new insurance products. 2. To further enchance the performance promotion of the insurance agent should more seriously to following the seminar, training, offering insurance products with a variety of innovations, so that prospective clients interested ini having an insurance policy with such production targets are achived impact insurance agent job satisfaction optimization.

Keyword: Intellectual Abilities, Performance Promotion and Job Satisfaction 


\section{A. PENDAHULUAN}

1. Latar Belakang Masalah

Pada dasarnya kepuasan kerja merupakan hal yang bersifat individual karena setiap individu akan memiliki tingkat kepuasan yang berbeda. Sesuai dengan nilai yang berlaku dalam diri setiap individu, semakin banyak aspek pekerjaan yang sesuai dengan peranan individu maka semakin tinggi tingkat kepuasan yang dirasakan. Kepuasan kerja merupakan sikap umum terhadap pekerjaan seseorang yang menunjukkan perbedaan antara jumlah penghargaan yang diterima pekerja dan jumlah yang mereka yakin seharusnya mereka terima.

PT Prudential Life Assurance Cabang Pruaini Agency PS8 Pematangsiantar yang berlokasi di jalan Dr. Wahidin No.101b Kota Pematangsiantar, salah satu perusahaan yang bergerak di bidang industri asuransi yang memberikan pelayanan jasa kepada masyarakat umum yang ingin memanfaatkan jasa asuransi sebagai upaya pengalihan resiko kehidupan yang pasti terjadi cepat atau lambat secara finansial.

PT Prudential Life Assurance Cabang Pruaini Agency PS8 Pematangsiantar terkait dengan kepuasan kerja agen asuransi yang memperhatikan dimensi kepuasan kerja agen asuransinya seperti: pekerjaan itu sendiri adalah kesempatan untuk belajar dan kesempatan menerima tanggung jawab, gaji atau imbalan yang dirasakan adil adalah jika didasarkan pada tuntutan-tuntutan pekerjaan disesuaikan tingkat keterampilan individu dan standar gaji yang berlaku sehingga menimbulkan kepuasan kerja, kesempatan promosi adalah adanya kemungkinan agen asuransi untuk memiliki kesempatan maju dalam organisasi tersebut, pengawasan yang wajar adalah adanya petunjuk dalam pelaksanaan kerja menyangkut cara-cara atasan dalam memperlakukan bawahannya, rekan kerja adalah sebagai sumber dukungan, kenyamanan, nasihat dan bantuan pada anggota individu dan kondisi kerja adalah kebutuhan-kebutuhan fisik yang disediakan perusahaan dalam menunjang kinerja yang diterima oleh para agen asuransi.

Salah satu faktor yang mempengaruhi kepuasan kerja agen asuransi PT Prudential Life Assurance Cabang Pruaini Agency PS8 Pematangsiantar adalah kemampuan intelektual. Adapun dimensi kemampuan intelektual yaitu kecerdasan angka, pemahaman verbal, kecepatan persepsi, penalaran induktif, penalaran deduktif, visualisasi spasial dan daya ingat. Pada dimensi kecerdasan angka agen asuransi dilatih untuk dapat melakukan perhitunganperhitungan finansial yang berhubungan dengan produk asuransi. Pada dimensi pemahaman verbal yaitu agen asuransi dilatih akan cara-cara memahami kebutuhan nasabah ataupun calon nasabahnya melalui apa yang didengarnya. Pada dimensi kecepatan persepsi yaitu agen asuransi dilatih untuk dapat menggunakan ilmu asuransi dalam menyelesaikan tugas sebagai dimensi pekerjaan. Selanjutnya pada dimensi penalaran induktif agen asuransi dilatih untuk dapat mengenali dan menyelesaikan masalah berdasarkan urutan logis yang berhubungan dengan proses klaim nasabah.

Faktor lain yang mempengaruhi kepuasan kerja agen asuransi PT Prudential Life Assurance Cabang Pruaini Agency PS8 Pematangsiantar adalah promosi jabatan. Adapun faktor-faktor yang mempengaruhi promosi jabatan antara lain: kejujuran, loyalitas, tingkat pendidikan, pengalaman kerja, dan inisiatif. Pada faktor kejujuran agen asuransi dilatih untuk dapat melakukan prospek dan rekrut dengan jujur tanpa menambahi ataupun mengurangi arti dari informasi produk asuransi ataupun jenjang karir dalam perusahaan dalam hal rekrut. Pada faktor loyalitas agen asuransi dilatih untuk setia akan pekerjaannya dengan mewujudkan pelayanan yang terbaik akan kebutuhan nasabahnya dalam jangka panjang.

\section{Rumusan Masalah}

a. Bagaimana gambaran kemampuan intelektual, promosi jabatan dan kepuasan kerja agen asuransi pada PT Prudential Life Assurance cabang Pruaini Agency PS8 Pematangsiantar.

b. Bagaimana pengaruh kemampuan intelektual, promosi jabatan dan kepuasan kerja agen asuransi pada PT Prudential Life Assurance Cabang Pruaini Agency PS8 Pematangsiantar.

\section{Tujuan Penelitian}

a. Untuk mengetahui gambaran kemampuan intelektual, promosi jabatan dan kepuasan kerja agen asuransi pada PT Prudential Life Assurance cabang Pruaini Agency PS8 Pematangsiantar.

b. Untuk mengetahui pengaruh kemampuan intelektual, promosi jabatan dan kepuasan kerja agen asuransi pada PT Prudential Life Assurance cabang Pruaini Agency PS8 Pematangsiantar baik secara simultan dan parsial.

\section{Metode Penelitian}

Yang menjadi objek penelitian ini adalah seluruh agen asuransi pada PT Prudential Life Assurance cabang Pruaini Agency PS8 Pematangsiantar yang aktif dan produktif yang terletak di jalan Dr.Wahidin No, 101b Kelurahan Siantar Selatan Kecamatan Siantar Selatan. Populasi adalah seluruh jumlah agen asuransi yang aktif terhitung dari bulan januari tahun 2017. Maka jumlah populasi adalah 120 orang agen asuransi. 
Adapun desain penelitian yang digunakan dalam penulisan jurnal ini adalah penelitian kepustakaan (library research) dan penelitian lapangan (field research). Teknik pengumpulan data yang dilakukan penulis dalam penelitian ini adalah berupa kuesioner, wawancara dan dokumentasi. Jenis data yang digunakan dalam penelitian ini adalah jenis data kualitatif dan data kuantitatif. Hasil data yang diperoleh dari lapangan akan dianalisis secara deskriptif baik bersifat kualitatif dan kuantitatif.

\section{B. LANDASAN TEOR}

\section{Manajemen Sumber Daya Manusia}

\section{a. Manajemen}

Menurut Robbins dan Timothy (2009:8), manajemen adalah pengkoordinasian kegiatan-kegiatan pekerjaan sehingga pekerjaan tersebut terselesaikan secara efisien dan efektif dan melalui orang lain. Menurut Griffin (2004:27), manajemen adalah serangkaian aktivitas (termasuk perencanaan dan pengambilan keputusan, pengorganisasian, kepemimpinan dan pengendalian) yang diarahkan pada sumbersumber daya organisasi (manusia, finansial, fisik, dan informasi) dengan maksud untuk mencapai tujuan organisasi secara efisien dan efektif. Dari pendapat para ahli tersebut dapat disimpulkan, bahwa manajemen adalah pengkoordinasian kegiatan-kegiatan organisasi untuk mencapaitujuan organisasi secara efektif dan efisien.

\section{b. Manajemen Sumber Daya Manusia}

Menurut Mondy (2008:10), manajemen sumber daya manusia adalah pemanfaatan sejumlah individu untuk mencapai tujuantujuan organisasi. Menurut Mathis dan John (2006:3), manajemen sumber daya manusia adalah rancangan sistem-sistem formal dalam sebuah organisasi untuk memastikan penggunaan bakat manusia secara efektif dan efisien guna mencapai tujuan-tujuan organisasi.Berdasarkan beberapa pendapat ahli tersebut, dapat disimpulkan manajemen sumber daya manusia adalah bagian dari manajemen keorganisasian yang memfokuskan diri terhadap sumber daya manusia. Tujuan dari manajemen sumber daya manusia adalah mengelola manusia secara baik agar menghasilkan manusia-manusia yang berkualitas.

\section{Kemampuan Intelektual}

Menurut Robbins and Timothy (2009:57), kemampuan intelektual adalah kemampuan mental yang diperlukan untuk melakukan berbagai aktivitas berpikir, menalar, dan memecahkan masalah. Menurut Sutrisno (2011:272), kecerdasan intelektual merupakan kemampuan yang diperlukan untuk menjalankan kegiatan mental. Berdasarkan dari uraian tersebut, dapat disimpulkan bahwa kemampuan intelektual adalah kemampuan dari individu untuk melaksanakan tugas dan kegiatan serta mengenali kemampuan sendiri dan dapat menjadi motivasi pada diri sendiri dan orang lain. Menurut Robbins dan Timothy (2009:58), yang dapat dijadikan dimensi pengukuran kemampuan intelektual dalam pekerjaan, yaitu:kecerdasan angka, pemahaman verbal, kecepatan persepsi, penalaran induktif, penalaran deduktif, visualisasi spasial dan daya ingat.Menurut Luthans (2006:332), dimensi kemampuan intelektual terbagi menjadi enam bagian diantaranya: pemahaman verbal, pemahaman numeric, visualisasi spatial, kecepatan perseptual, memori dan pemikiran induktif. Berdasarkan uraian tersebut dapat disimpulkan bahwa dimensi pengukuran dalam kemampuan intelektual adalah kecerdasan angka, pemahaman verbal, kecepatan persepsi, penalaran induktif, penalaran deduktif dan daya ingat, sementara visualisasi spasial tidak dipakai sebagai alat ukur.

\section{Promosi Jabatan}

Menurut Dessler (2007:12), promosi jabatan adalah bagian yang terintegrasi dari sebagian besar karir seseorang. Promosi dulunya mengacu kepada kemajuan ke posisi dan tanggung jawab yang meningkat. Menurut Mangkuprawira (2003:168), promosi jabatan adalah proses penugasan kembali seseorang karyawan ke posisi pekerjaan yang lebih tinggi. Berdasarkan pendapat para ahli tersebut dapat disimpulkan bahwa promosi jabatan adalah perpindahan posisi/ jabatan atau pekerjaan/ penugasan kembali seorang pegawai/ karyawan dari tingkat rendah ke tingkat yang lebih tinggi. Menurut Wahyudi (2002:173) ada lima faktor yang mempengaruhi promosi jabatan diantaranya: kejujuran, loyalitas, tingkat pendidikan, pengalaman kerja dan inisiatif. Menurut Nitisemito (2007:112) ada delapan faktor yang mempengaruhi promosi jabatan diantaranya: pengalaman, tingkat pendidikan, loyalitas, kejujuran, tanggung jawab, kepandaian bergaul, prestasi kerja, inisiatif dan kreatif. Berdasarkan uraian tersebut, dapat disimpolkan bahwa faktorfaktor promosi jabatan yaitu:kejujuran, loyalitas, tingkat pendidikan, pengalaman kerja dan inisiatif.sebagai pertimbangan untuk dilakukannya promosi jabatan.

\section{Kepuasan Kerja}

Menurut Luthans (2006:243), kepuasan kerja adalah hasil dari persepsi karyawan mengenai seberapa baik pekerjaan mereka memberikan hal yang dinilai penting. Sedangkan menurut Kreitner dan Angelo 
(2014:169) mengemukakan kepuasan kerja adalah sebuah tanggapan afektif atau emosional terhadap berbagai segi pekerjaan seseorang. Definisi ini menyatakan secara tidak langsung bahwa kepuasan kerja bukanlah merupakan konsep kesatuan. Namun, seseorang bisa merasa cukup puas dengan salah satu aspek pekerjaannya dan merasa kurang puas dengan satu atau beberapa aspek lainnya.Dari uraian tersebut, dapat disimpulkan bahwa kepuasan kerja adalah sikap karyawan yang memandang seberapa baik mereka memandang pekerjaan mereka yang menggambarkan perasaan senang atau tidak senang, puas ataupun tidak puas dalam bekerja. Hal ini terlihat dalam sikap positif karyawan terhadap pekerjaan dan segala sesuatu yang dihadapi di lingkungan kerja.Menurut Robbins dan Timothy (2009:113) ada empat faktor yang mempengaruhi kepuasan kerja diantaranya: pekerjaan yang secara mental menantang, imbalan yang wajar, kondisi lingkungan kerja yang mendukung, dan rekan kerja yang suportif. Menurut Luthans (2006:243) ada enam faktor yang mempengaruhi kepuasan kerja diantaranya: pekerjaan itu sendiri, gaji atau imbalan yang dirasakan adil, adanya kesempatan promosi, pengawasan yang wajar, rekan kerja dan kondisi kerja. Berdasarkan uraian tersebut, dapat disimpulkan bahwa banyak terdapat faktor yang menunjang demi tercapainya kepuasan kerja dalam mencapai tujuan organisasi seperti gaji, atasan, rekan kerja, promosi lingkungan kerja dan pekerjaan itu sendiri.

\section{PEMBAHASAN \\ 1. Analisa}

\section{a. Deskriptif Kualitati}

Analisis deskriptif kuantitatif dimaksudkan untuk mendapatkan gambaran atau deskripsi mengenai pengaruh kemampuan intelektual dan promosi jabatan terhadap kepuasan agen asuransi pada PT Prudential Life Assurance cabang Pruaini Agency PS8 Pematangsiantar. Adapun penetapan kriteria nilai rata-rata jawaban dari responden tersebut dimasukkan kedalam kelas-kelas interval dimana penentuan intervalnya memakai rumus sebagai berikut: Interval Kelas $=$ Nilai Tertingai - Nilai Terendah

$$
\text { Jumlah Kelas }
$$

Dari rumus diatas dapat diperoleh interval kelas 0,8 sehingga berlaku ketentuan indikator dengan hasil sebagai berikut:

$$
\text { Tabel } 1
$$

Nilai Interval dan Indikator Jawaban Responden

\begin{tabular}{|c|c|c|c|}
\hline \multirow{2}{*}{$\begin{array}{c}\text { Nilai } \\
\text { Interval }\end{array}$} & \multicolumn{3}{|c|}{ Indikator } \\
\cline { 2 - 4 } & $\begin{array}{c}\text { Kemampuan } \\
\text { Intelektual }\end{array}$ & $\begin{array}{c}\text { Promosi } \\
\text { Jabatan }\end{array}$ & $\begin{array}{c}\text { Kepuasan } \\
\text { Kerja }\end{array}$ \\
\hline $1,00-$ & Sangat & Sangat & Sangat \\
\hline
\end{tabular}

\begin{tabular}{|c|c|c|c|}
\hline 1,80 & Tidak Baik & $\begin{array}{c}\text { Tidak } \\
\text { Baik }\end{array}$ & $\begin{array}{c}\text { Tidak } \\
\text { Puas }\end{array}$ \\
\hline $\begin{array}{c}1,81- \\
2,60\end{array}$ & Tidak Baik & $\begin{array}{c}\text { Tidak } \\
\text { Baik }\end{array}$ & $\begin{array}{c}\text { Tidak } \\
\text { Puas }\end{array}$ \\
\hline $\begin{array}{c}2,61- \\
3,40\end{array}$ & Cukup Baik & $\begin{array}{c}\text { Cukup } \\
\text { Baik }\end{array}$ & $\begin{array}{c}\text { Cukup } \\
\text { Puas }\end{array}$ \\
\hline $\begin{array}{c}3,41- \\
4,20\end{array}$ & Baik & Baik & Puas \\
\hline $\begin{array}{c}4,21- \\
5,00\end{array}$ & Sangat Baik & $\begin{array}{c}\text { Sangat } \\
\text { Baik }\end{array}$ & $\begin{array}{c}\text { Sangat } \\
\text { Puas }\end{array}$ \\
\hline
\end{tabular}

Sumber: Sugiyono (2013)

1) Gambaran Kemampuan Intelektual Pada PT Prudential Life Assurance Cabang Pruaini Agency PS8 Pematangsiantar

Dari hasil analisa, untuk dimensi kecerdasan angka pada indikator tingkat kemampuan dalam berhitung cepat berada pada rata-rata 4,05 dengan kriteria jawaban baik. Hal ini disebabkan agen asuransi yang memiliki kemampuan berhitung dengan baik dan didukung dengan latar belakang pendidikan yang tinggi. Pada indikator tingkat kemampuan agen dalam mengerjakan tugas berada pada rata-rata 3,91 dengan kriteria jawaban baik. Hal ini disebabkan hampir semua agen asuransi mampu dalam menyelesaikan tugasnya dengan baik dan tepat waktu. Selanjutnya pada indikator usaha yang dilakukan agen asuransi dalam memecahkan masalah perhitungan berada pada rata-rata 3,97 dengan kriteria jawaban baik. Hal ini disebabkan karena agen aktif selalu mengikuti pelatihan dan seminar yang diadakan oleh PT Prudential Life Assurance Cabang Pruaini Agency PS8 Pematangsiantar tentang hitung-hitungan yang berkaitan dengan asuransi.Pada dimensi pemahaman verbal, untuk indikator kemampuan agen asuransi dalam memahami apa yang dibaca berada pada rata-rata 3,82 dengan kriteria jawaban baik. Hal ini disebabkan karena masih ada agen asuransi yang belum mampu membuat ilustrasi proposal menggunakan aplikasi dengan berbagai jenis manfaat yang berbedabeda mengacu kepada kebutuhan calon nasabahnya. Pada indikator kemampuan agen asuransi dalam memahami apa yang didengar berada pada rata-rata 3,25 dengan kriteria jawaban cukup baik. Hal ini disebabkan karena agen asuransi belum optimal memahami kebutuhan nasabah maupun calon nasabahnya melalui apa yang didengarnya. Selanjutnya pada indikator kemampuan agen dalam menyampaikan pendapatnya berada pada rata-rata 3,85 dengan kriteria jawaban baik. Hal ini disebabkan adanya kebebasan menyampaikan pendapat yang diberikan PT Prudential Life Assurance Cabang Pruaini Agency PS8 Pematangsiantar pada para agen asuransinya baik saat acara resmi maupun non resmi untuk kemajuan perusahaan. 
Pada dimensi kecepatan persepsi, untuk indikator kemampuan agen asuransi dalam mengenal kemiripan suatu permasalahan berada pada rata-rata 4,14 dengan kriteria jawaban baik. Hal ini disebabkan aktifnya agen asuransi dalam mengikuti monday morning motivation (M3), sharing motivasi yang diadakan PT Prudential Life Assurance Cabang Pruaini Agency PS8 Pematangsiantar dalam mendiskusikan permasalahan yang ada di lapangan. Pada indikator kemampuan agen asuransi berfikir dalam menyelesaikan tugas sebagai dimensi pekerjaan berada pada ratarata 4,00 dengan kriteria jawaban baik. Hal ini disebabkan sedikitnya ruang berpikir agen asuransi dalam menyelesaikan tugas karena para agen asuransi dilatih untuk kreatif mengedukasikan manfaat asuransi pada calon nasabahnya dengan cara prospek dan rekrut. Selanjutnya pada indikator kemampuan agen mengidentifikasi perbedaan suatu permasalahan berada pada rata-rata 3,91 dengan kriteria jawaban baik. Hal ini disebabkan karena belum semua agen asuransi dapat mengidentifikasi perbedaan permasalahan yang ada berhubungan dengan proses klaim nasabah.Pada dimensi penalaran induktif, untuk indikator kemampuan agen asuransi dalam mengenali masalah dan menyelesaikannya berdasarkan urutan logis berada pada rata-rata 3,57 dengan kriteria jawaban baik. Hal ini terlihat dari kemampuan agen asuransi yang belum merata dalam mengenali dan menyelesaikan masalah berdasarkan urutan logis. Pada indikator kemampuan agen asuransi dalam mengenali masalah berada pada rata-rata 3,57 dengan kriteria jawaban baik. Hal ini disebabkan setiap agen asuransi PT Prudential Life Assurance Cabang Pruaini Agency PS8 Pematangsiantar memiliki kemampuan yang berbeda-beda dalam mengenali masalah. Selanjutnya pada indikator keinginan agen asuransi dalam memecahkan masalah berada pada rata-rata 3,91 dengan kriteria jawaban baik. Hal ini disebabkan karena adanya keinginan agen asuransi untuk fokus melihat peluang yang ada ditengah permasalahan yang dihadapinya.

Pada dimensi penalaran deduktif, untuk indikator logika berpikir agen asuransi dalam menilai suatu argumen yang diberikan berada pada rata-rata 4,17 dengan kriteria jawaban baik. Hal ini disebabkan agen asuransi PT Prudential Life Assurance Cabang Pruaini Agency PS8 Pematangsiantar telah diperlengkapi dengan makna yang mendasar akan profesi sebagai agen asuransi. Pada indikator kecakapan agen asuransi dalam menjalankan tugas berada pada rata-rata 4,02 dengan kriteria jawaban baik. Hal ini disebabkan para agen asuransi sadar akan manusia sebagai makhluk sosial yang tidak bisa lepas dari individu lainnya. Selanjutnya pada indikator agen asuransi mampu bekerja dengan baik secara fleksibel berada pada ratarata 3,91 dengan kriteria jawaban baik. Hal ini disebabkan karena fleksibilitas agen asuransi dalam menggunakan logika berpikir, berhitung dalam bekerja belum optimal seperti setiap hari prospek setiap hari rekrut mengharuskan agen asuransi bertemu dengan orang-orang baru setiap harinya.Sementara pada dimensi daya ingat, untuk indikator kemampuan agen asuransi untuk mengenang kembali pengalaman kerja sebagai pembelajaran berada pada rata-rata 3,85 dengan kriteria jawaban baik. Hal ini disebabkan agen asuransi menggunakan ingatannya sebagai alat untuk menyimpan sesuatu hal yang berhubungan dengan asuransi yang pernah dipelajari dan dipahami sebelumnya. Pada indikator ingatan agen asuransi dalam mengingat kesalahan masa lalu sebagai pembelajaran berada pada rata-rata 3,94 dengan kriteria jawaban baik. Hal ini disebabkan pengalaman yang sudah dilalui agen asuransi tersebut dipahami dengan baik. Selanjutnya pada indikator memori agen asuransi mengingat suatu pekerjaan berada pada rata-rata 3,97 dengan kriteria jawaban baik. Hal ini disebabkan tingginya produktifitas kerja yang dilakukan agen asuransi pada masa lalu sehingga memiliki pengalaman yang tidak terlupakan.

Secara keseluruhan dapat dilihat bahwa nilai rata-rata kemampuan intelektual yang dimiliki setiap agen asuransi yang diberikan kepada responden berada pada nilai 3,88 dengan kriteria jawaban baik, kemudian nilai rata-rata tertinggi sebesar 4,17 dengan kriteria jawaban baik pada indikator logika berpikir agen asuransi dalam menilai suatu argumen yang diberikan sedangkan nilai rata-rata terendah sebesar 3,25 dengan indikator kemampuan agen asuransi dalam memahami apa yang didengar.

\section{2) Gambaran Promosi Jabatan Pada PT Prudential Life Assurance Cabang Pruaini Agency PS8 Pematangsiantar}

Dari hasil analisa, dapat dilihat bahwa dimensi kejujuran sebagai indikator kejujuran agen dalam melaksanakan tugas berada pada rata-rata 4,02 dengan kriteria jawaban baik, hal ini disebabkan kesadaran agen asuransi akan tanggung jawab pekerjaannya sebagai tenaga professional asuransi adalah tinggi. Indikator melaporkan hasil kerja yang baik kepada atasan (leader) memperoleh nilai rata-rata 3,65 dengan kriteria jawaban baik, hal ini disebabkan agen asuransi melakukan prospek dan rekrut dengan jujur tanpa menambahi ataupun mengurangi arti dari informasi produk asuransi ataupun jenjang karir dalam perusahaan dalam hal rekrut. Indikator melaksanakan penilaian prestasi kerja 
memperoleh nilai rata-rata 3,85 dengan kriteria jawaban baik, hal ini disebabkan fokusnya agen pada hasil yang diperoleh dalam setiap proses pengaplikasian rencana kerja.Pada dimensi loyalitas dengan indikator loyalitas agen asuransi terhadap perusahaan berada pada rata-rata 3,82 dengan kriteria jawaban baik. Hal ini disebabkan karena penghargaan (reward) yang ditawarkan perusahaan terhadap seluruh agen pemasarannya yang berhasil mengikuti ketentuan persyaratan promosi jabatan adalah sesuai dengan harapan agen asuransi. Indikator loyalitas agen asuransi terhadap pekerjaan berada pada rata-rata 3,71 dengan kriteria jawaban baik. Hal ini disebabkan selain komisi yang besar agen asuransi juga membantu pengurusan klaim yang bermanfaat bagi nasabahnya sesuai dengan kontrak buku polis yang dimiliki nasabahnya. Indikator loyalitas agen asuransi terhadap atasan berada pada rata-rata 3,62 dengan kriteria jawaban baik. Hal ini disebabkan karena fokusnya agen terhadap hasil yang akan dicapai bersama sehingga apapun yang menjadi rencana kerja atasan maka agen melaksanakannya dengan fokus pada hasil.

Pada dimensi tingkat pendidikan dengan indikator atasan (leader) mempromosikan jabatan kepada agen asuransi berada pada rata-rata 3,77 dengan kriteria jawaban baik. Hal ini disebabkan pekerjaan sebagai agen asuransi yang akan di promosikan lebih di titik beratkan kepada hasil kerja (action/prospek dan recruit). Indikator kriteria minimum dalam tingkat pendidikan berada pada rata-rata 3,74 dengan kriteria jawaban baik. Hal ini disebabkan karena setiap agen asuransi diberikan kesempatan untuk mengikuti kelas training nasional tentang asuransi dimana sertifikat agen asuransi yang diterima dari kelas training tersebut adalah diakui secara internasional guna menunjang karir agen asuransi. Indikator syarat yang harus dilakukan dalam mempromosikan agen asuransi berada pada rata-rata 3,65 dengan kriteria jawaban baik. Hal ini disebabkan karena syarat untuk promosi tidak semata-mata ditentukan oleh tingkat pendidikan melainkan hasil kerja yang dicapai oleh agen asuransi dan persistensi produksi agen asuransi yang baik.Pada dimensi pengalaman kerja dengan indikator inisiatif atasan dalam menetapkan promosi berdasarkan pengalaman berada pada ratarata 3,51 dengan kriteria jawaban baik. Hal ini disebabkan karena pengalaman kerja yang baik di lapangan sangat menentukan percepatan proses mencapai promosi jabatan. Indikator perusahaan menentukan syarat promosi berdasarkan pengalaman kerja berada pada rata-rata 3,68 dengan kriteria jawaban baik. Hal ini disebabkan syarat mutlak untuk capai promosi jabatan adalah hasil pencapaian kerja agen itu sendiri tanpa melihat lamanya agen asuransi menguasai bidang asuransi sebagai pengalaman kerja. Indikator pengalaman kerja agen digunakan sebagai kegiatan promosi perusahaan berada pada rata-rata 3,68 dengan kriteria jawaban baik. Hal ini disebabkan karena pengalaman kerja tidak menjadi penghalang untuk capai promosi jabatan baik itu agen baru maupun agen yang sudah lama.

Pada dimensi inisiatif dengan indikator inisiatif agen asuransi dalam mencapai promosi berada pada rata-rata 3,62 dengan kriteria jawaban baik. Hal ini disebabkan karena segala upaya untuk mencapai promosi sepenuhnya dari inisiatif agen itu sendiri. Indikator kreatif agen asuransi dalam mencapai promosi berada pada rata-rata 3,60 dengan kriteria jawaban baik. Hal ini disebabkan karena agen asuransi dituntut lebih bisa kreatif dalam bekerja, lebih mandiri dalam mengelola waktu dan kesempatan. Indikator inovatif agen asuransi dalam mencapai promosi berada pada rata-rata 3,22 dengan kriteria jawaban baik. Hal ini disebabkan karena agen asuransi belum dapat mengembangkan kreatifitas menjual produk asuransi secara inovatif tanpa menambahi ataupun mengurangi informasi produk yang ditawarkan kepada calon nasabahnya.

Secara keseluruhan, hasil dari kuesioner promosi jabatan memperoleh nilai rata-rata 3,68 dengan kriteria jawaban baik. Nilai ratarata tertinggi adalah 4,02 pada dimensi kejujuran dalam melaksanakan tugas sedangkan nilai rata-rata terendah sebesar 3,22 dengan indikator inovatif agen asuransi dalam mencapai promosi jabatan.

3) Gambaran Kepuasan Kerja Agen Asuransi Pada PT Prudential Life Assurance Cabang Pruaini Agency PS8 Pematangsiantar

Dari hasil analisa, dapat dilihat bahwa pada dimensi pekerjaan itu sendiri pada indikator tugas yang menantang berada pada rata-rata 3,91 dengan kriteria jawaban baik. Hal ini disebabkan agen asuransi menyadari sepenuhnya akan keberadaannya sebagai tenaga profesional penjual asuransi. Pada indikator kepuasan agen terhadap kesempatan yang diberikan perusahaan untuk mengembangkan keterampilan dalam bekerja berada pada rata-rata 3,97 dengan kriteria jawaban baik. Hal ini disebabkan setiap agen diberikan keleluasaan untuk berkarya melalui pelatihan yang disediakan perusahaan, seminar motivasi tiap minggunya untuk diikuti oleh para agen. Selanjutnya pada indikator kepuasan agen dengan posisi kerja saat ini yang sesuai dengan kemampuan berada pada rata-rata 3,82 dengan kriteria jawaban baik. Hal ini disebabkan karena masih kurangnya 
kesadaran agen asuransi akan pentingnya untuk meng-upgrade ilmu asuransi yang dimilikinya sehingga agen asuransi tersebut tidak mengalami kenaikan posisi kerja.Pada dimensi gaji atau imbalan yang dirasakan adil dengan indikator kepuasan agen terhadap gaji/imbalan yang ditetapkan perusahaan berada pada rata-rata 3,85 dengan kriteria jawaban baik. Hal ini disebabkan karena agen mendapatkan komisi sesuai dengan harapan. Indikator kepuasan agen dengan gaji/imbalan yang diberikan adil dan tepat waktu berada pada rata-rata 3,85 dengan kriteria jawaban baik. Hal ini disebabkan karena komisi yang diterima agen selalu tepat waktu sesuai dengan schedule income yang diinformasikan perusahaan kepada seluruh agen pemasarannya. Selanjutnya pada indikator kepuasan agen dengan gaji/imbalan yang diberikan perusahaan sesuai dengan beban kerja berada pada rata-rata 3,94 dengan kriteria jawaban baik. Hal ini disebabkan karena komisi yang diterima agen belum sesuai dengan beban kerja yang diembannya.

Pada dimensi kesempatan promosi dengan indikator kepuasan agen terhadap kesempatan promosi berdasarkan kinerja berada pada rata-rata 3,85 dengan kriteria jawaban baik. Hal ini disebabkan karena hasil kinerja yang capai target akan mendapatkan apresiasi yang baik dari perusahaan sehingga menciptakan kepuasan kerja agen. Indikator kepuasan agen asuransi dengan pelatihan yang diberikan perusahaan dalam mengembangkan karir berada pada rata-rata 3,34 dengan kriteria jawaban cukup baik. Hal ini disebabkan karena kebijakan promosi yang ditetapkan perusahaan dirasa terlalu berat untuk mencapainya Selanjutnya pada indikator kepuasan agen dengan kebijakan promosi yang berlangsung saat ini berada pada ratarata 3,65 dengan kriteria jawaban baik. Hal ini disebabkan karena agen asuransi merasa belum puas dengan kebijakan perusahaan akan kesempatan promosi terhadap setiap agen.Pada dimensi pengawasan yang wajar dengan indikator kepuasan dengan tingkat pengawasan yang diberikan perusahaan berada pada rata-rata 3,91 dengan kriteria jawaban baik. Hal ini disebabkan karena pengawasan yang dirasakan agen tidak mempersempit ruang gerak agen dalam bekerja. Indikator kepuasan agen terhadap cara atasan (leader) dalam memberikan petunjuk pelaksanaan kerja berada pada ratarata 3,88 dengan kriteria jawaban baik. Hal ini disebabkan karena petunjuk yang diterima agen dari atasan adalah jelas dan memberikan pandangan yang mudah dipahami agen. Selanjutnya pada indikator kepuasan agen jika selalu diperhatikan/diawasi saat bekerja berada pada rata-rata 3,82 dengan kriteria jawaban baik. Hal ini disebabkan agen tidak terlalu suka diperhatikan/diawasi saat bekerja.

Pada dimensi rekan kerja dengan indikator kepuasan agen terhadap interaksi sesama rekan kerja berada pada rata-rata 3,94 dengan kriteria jawaban baik. Hal ini disebabkan karena kepedulian antar sesama rekan kerja yang diterapkan perusahaan dengan semboyan 'greather, faster, stronger' mampu memperkuat kerja sama terhadap rekan kerja. Indikator kepuasan agen terhadap perhatian sesama rekan kerja berada pada rata-rata 3,31 dengan kriteria jawaban cukup baik. Hal ini disebabkan karena adanya agen asuransi yang melakukan follow up calon nasabahnya sendiri-sendiri tanpa mengajak rekan kerjanya setelah diadakannya group selling (GS) calon nasabah. Selanjutnya pada indikator kepuasan agen dengan dukungan dari rekan kerja dalam menyelesaikan persoalan yang menyangkut pekerjaan berada pada rata-rata 3,94 dengan kriteria jawaban baik. Hal ini disebabkan karena tulusnya agen membagikan pengalaman kerjanya yang menyangkut persoalan-persoalan yang dilaluinya dahulu kepada agen sebagai pembangkit semangat bekerja.Pada dimensi kondisi kerja dengan indikator kepuasan agen dengan lingkungan kerja yang nyaman berada pada rata-rata 3,85 dengan kriteria jawaban baik. Hal ini disebabkan karena adanya sekretaris pembantu agen yang siap sedia membantu agen dalam hal proses pengajuan SPAJ, proses penerbitan buku polis, dan proses pengklaiman serta hal lainnya yang berhubungan dengan percepatan pekerjaan agen. Indikator kepuasan agen dengan fasilitas yang diberikan perusahaan berada pada ratarata 3,88 dengan kriteria jawaban baik. Hal ini disebabkan karena fasilitas pelengkap untuk menunjang kelancaran pekerjaan agen asuransi seperti perangkat computer dan printer yang masih berpusat pada satu central processing unit (CPU) sehingga memperlambat kinerja agen asuransi dalam membuat dan mencetak lembaran ilustrasi proposal tersebut. Selanjutnya pada indikator kepuasan agen dengan kemudahan yang diberikan perusahaan untuk bekerja dengan baik berada pada rata-rata 3,65 dengan kriteria jawaban baik. Hal ini disebabkan karena kemudahan agen dalam memproses berkasberkas yang berhubungan dengan karir agen dipermudah perusahaan dengan adanya pendirian kantor cabang di daerah kota pematangsiantar.

Secara keseluruhan dapat dilihat bahwa nilai rata-rata kepuasan kerja yang dirasakan setiap agen asuransi sebagai responden berada pada nilai 3,80 dengan kriteria jawaban baik, kemudian nilai rata-rata tertinggi sebesar 3,97 dengan kriteria jawaban baik berada pada dimensi kesempatan promosi indikator 
kepuasan agen dengan gaji/imbalan yang diberikan adil dan tepat waktu sedangkan nilai rata-rata terendah sebesar 3,31 dengan dimensi rekan kerja sebagai indikator kepuasan agen terhadap perhatian sesama rekan kerja.

\section{b. Deskriptif Kuantitatif}

\section{1) Regresi Linear Berganda}

$$
\text { untuk menganalisa }
$$

pengaruh kemampuan intelektual dan promosi jabatan terhadap kepuasan kerja pada PT Prudential Life Assurance cabang Pruaini Agency PS8 Pematangsiantar secara bersama-sama. Dengan menggunakan bantuan program SPSS 21, didapatkan hasil regresi sebagai berikut: Tabel 2

Hasil Regresi Linier Berganda coefficients ${ }^{a}$

\begin{tabular}{|l|r|r|r|}
\hline \multirow{2}{*}{ Model } & \multicolumn{2}{|c|}{\begin{tabular}{l}
\multicolumn{2}{|c|}{ Unstandardize } \\
d Coefficients
\end{tabular}} & $\begin{array}{c}\text { Standar } \\
\text { dized } \\
\text { Coefficie } \\
\text { nts }\end{array}$ \\
\cline { 2 - 4 } & $B$ & $\begin{array}{c}\text { Std. } \\
\text { Error }\end{array}$ & Beta \\
\hline $\begin{array}{l}\text { (Constant) } \\
\text { Kemampua } \\
\text { n }\end{array}$ & $\begin{array}{r}10.85 \\
0\end{array}$ & 8.778 & \\
$\begin{array}{l}\text { Intelektual } \\
\left(\mathbf{X}_{1}\right)\end{array}$ & & .156 & .474 \\
$\begin{array}{l}\text { Promosi } \\
\text { Jabatan } \\
\left(\mathbf{X}_{2}\right)\end{array}$ & .418 & .171 & .365 \\
\hline
\end{tabular}

a. Dependent Variable: $Y$

Sumber: pengolahan data kuesioner (SPSS 21)

Berdasarkan hasil pengolahan data pada table di atas diperoleh persamaan regresi sebagai berikut: $\hat{Y}=10,850+0,494 X_{1}+$ $0,418 X_{2}$ artinya terdapat pengaruh positif antara kemampuan intelektual dan promosi jabatan terhadap kepuasan kerja pada PT Prudential Life Assurance Cabang Pruaini PS8 Pematangsiantar.

\section{2) Koefisien Korelasi dan Koefisien Determinasi}

Pada tahap ini akan dihitung korelasi berupa derajat atau kedalaman hubungan fungsional yang menjelaskan hubungan antarperubah, disebut dengan koefisien yang disimbolkan dengan r. pada uji kali ini dihitung secara keseluruhan antara variabel bebas kemampuan intelektual dan promosi jabatan terhadap variabel kepuasan kerja. Untuk mengukur seberapa besar variabel bebas menjelaskan variabel terikat maka digunakan koefisien determinasi (KD). Berikut ini adalah hasil uji koefisien determinasi secara simultan antara variabel bebas kemampuan intelektual dan promosi jabatan dengan variabel terikat kepuasan kerja. Dengan menggunakan bantuan program SPSS Versi 21 didapatkan hasil perhitungan koefisien korelasi sebagai berikut:

\begin{tabular}{|r|r|r|r|r|}
\multicolumn{9}{|c|}{ ModelSummary } \\
\hline $\begin{array}{r}\text { Mo } \\
\text { del }\end{array}$ & $R$ & $\begin{array}{c}\boldsymbol{R} \\
\text { Squar } \\
e\end{array}$ & $\begin{array}{c}\text { Adjus } \\
\text { ted } R \\
\text { Squar } \\
\boldsymbol{e}\end{array}$ & $\begin{array}{c}\text { Std. Error of } \\
\text { the Estimate }\end{array}$ \\
\hline 1 & $\begin{array}{r}.761 \\
\mathrm{a}\end{array}$ & .579 & .553 & 6.224 \\
\hline
\end{tabular}

a. Predictors: (Constant), Kemampuan Intelektual, Promosi Jabatan.

b. Dependent Variable: Kepuasan Kerja. Sumber: hasil pengolahan data SPSS Versi 21.

\section{3) Uji Hipotesis}

a) Uji Simultan (Uji F)

Pengujian ini dilakukan secara simultan yaitu dilakukan untuk menentukan diterima atau ditolaknya hipotesis, pengujian hipotesis dilakukan untuk mengetahui apakah variabel kemampuan intelektual dan promosi jabatan yang diuji berpengaruh terhadap kepuasan pelanggan. Jika tingkat signifikansi $\leq 0,05$ maka $\mathrm{H}_{0}$ ditolak.

Tabel 4

Perkiraan Nilai $F_{\text {hitung }}$

ANNOVA

\begin{tabular}{|c|c|c|c|c|c|}
\hline Model & $\begin{array}{l}\text { Sum } \\
\text { of } \\
\text { Squar } \\
\text { es }\end{array}$ & Df & $\begin{array}{c}\text { Mean } \\
\text { Squar } \\
\text { e }\end{array}$ & $F$ & Sig. \\
\hline $\begin{array}{l}\text { Regre } \\
\text { ssion } \\
{ }_{1} \text { Resid } \\
\text { ual } \\
\text { Total }\end{array}$ & $\begin{array}{r}1707 . \\
168 \\
1239 . \\
518 \\
2946 . \\
686\end{array}$ & $\begin{array}{l}32 \\
34\end{array}$ & $\begin{array}{r}853.5 \\
84 \\
38.73 \\
5\end{array}$ & $\begin{array}{r}22.03 \\
7\end{array}$ & $.000^{\mathrm{b}}$ \\
\hline
\end{tabular}

a. Dependent Variable: $Y$

b. Predictors: (Constant), X2, X1

Sumber: hasil pengolahan data SPSS Versi 21.

Dari hasil analisis pada tabel di atas diperoleh tingkat signifikansi $0,000 \leq 0,05$ maka $\mathrm{H}_{0}$ ditolak, artinya kemampuan intelektual dan promosi jabatan berpengaruh positif dan signifikansi terhadap kepuasan kerja agen asuransi pada PT Prudential Life Assurance Cabang Pruaini Agency PS8 Pematangsiantar.

\section{b) Uji Parsial (Uji t)}

Pengujian ini dilakukan secara parsial yaitu dilakukan untuk menentukan diterima atau ditolaknya hipotesis, pengujian hipotesis dilakukan untuk mengetahui apakah variabel 
kemampuan intelektual dan promosi jabatan yang diuji berpengaruh terhadap kepuasan kerja agen asuransi. Jika tingkat signifikansi $\leq$ 0,05 maka $\mathrm{H}_{0}$ ditolak.

Tabel 5

Perkiraan Nilai thitung

Coefficients $^{a}$

\begin{tabular}{|c|c|c|c|c|c|}
\hline \multirow[t]{2}{*}{ Model } & \multicolumn{2}{|c|}{$\begin{array}{c}\text { Unstandar } \\
\text { dized } \\
\text { Coefficient } \\
\text { s }\end{array}$} & $\begin{array}{l}\text { Standar } \\
\text { dized } \\
\text { Coeffici } \\
\text { ents } \\
\end{array}$ & $t$ & Sig. \\
\hline & $B$ & $\begin{array}{c}\text { Std. } \\
\text { Erro } \\
r\end{array}$ & Beta & & \\
\hline $\begin{array}{l}\text { (Cons } \\
\text { tant) }\end{array}$ & $\begin{array}{r}10.8 \\
50\end{array}$ & $\begin{array}{r}8.77 \\
8\end{array}$ & & $\begin{array}{r}1.2 \\
36\end{array}$ & .225 \\
\hline X1 & .494 & .156 & .474 & $\begin{array}{r}3.1 \\
67\end{array}$ & .003 \\
\hline $\mathrm{X} 2$ & .418 & .171 & .365 & $\begin{array}{r}2.4 \\
41\end{array}$ & .020 \\
\hline
\end{tabular}

a. Dependent Variable: $Y$

Sumber: hasil pengolahan data SPSS Versi 21.

Berdasarkan hasil analisis pada tabel di atas dapat dilihat pada variabel kemampuan intelektual $\left(X_{1}\right)$ diperoleh signifikansi $0,005 \leq \alpha$ 0,05 maka $H_{0}$ ditolak artinya kemampuan intelektual berpengaruh positif dan signifikan terhadap kepuasan kerja agen asuransi pada PT Prudential Life Assurance Cabang Pruaini Agency PS8 Pematangsiantar. Variabel promosi jabatan $\left(\mathrm{X}_{2}\right)$ diperoleh signifikansi $0,000 \leq \alpha \quad 0,05$ maka $\mathrm{H}_{0}$ ditolak artinya promosi jabatan berpengaruh positif dan signifikan terhadap kepuasan kerja agen asuransi pada PT Prudential Life Assurance Cabang Pruaini Agency PS8 Pematangsiantar.

\section{Evaluasi}

\section{a. Kemampuan Intelektual Pada PT Prudential Life Assurance Cabang Pruaini Agency PS8 Pematangsiantar}

Berdasarkan dimensi yang digunakan dalam penelitian ini, hasil yang diperoleh dapat dijelaskan bahwa kemampuan intelektual yang diterapkan pada PT Prudential Life Assurance Cabang Pruaini PS8 Pematangsiantar dapat dikatakan baik, hal tersebut dapat dilihat dari hasil kuesioner yang diperoleh nilai rata-rata 3,88 berkriteria baik. Pada dimensi pemahaman verbal, untuk indikator kemampuan agen asuransi dalam memahami apa yang didengar berada pada rata-rata 3,25 dengan kriteria jawaban cukup baik. Pada dimensi penalaran induktif, untuk indikator kemampuan agen asuransi dalam mengenali masalah dan menyelesaikannya berdasarkan urutan logis berada pada rata-rata 3,57 dengan kriteria jawaban baik. Hal ini terlihat dari seringnya agen asuransi menemui nasabah maupun calon nasabah yang terlalu cepat mengambil suatu kesimpulan negatif akan isu permasalahan yang beredar di masyarakat tanpa menanyakan kepada yang ahli dalam bidang asuransi yakni agen asuransi.

Pada indikator kemampuan agen asuransi dalam mengenali masalah berada pada rata-rata 3,57 dengan kriteria jawaban baik. Hal ini disebabkan para agen asuransi PT Prudential Life Assurance Cabang Pruaini Agency PS8 Pematangsiantar telah diperlengkapi dengan makna yang mendasar akan profesi sebagai agen asuransi. Sementara pada dimensi daya ingat, untuk indikator kemampuan agen asuransi dalam mengenang kembali pengalaman kerja sebagai pembelajaran berada pada rata-rata 3,85 dengan kriteria jawaban baik. Hal ini disebabkan agen asuransi menggunakan ingatannya sebagai alat untuk menyimpan sesuatu hal yang berhubungan dengan asuransi yang pernah dipelajari dan dipahami. Secara keseluruhan dapat dilihat bahwa nilai rata-rata kemampuan intelektual yang dimiliki setiap agen asuransi yang diberikan kepada responden berada pada nilai 3,88 dengan kriteria jawaban baik, kemudian nilai rata-rata tertinggi sebesar 4,17 dengan kriteria jawaban baik pada indikator kemampuan agen asuransi dalam menggunakan logika berpikir, sedangkan nilai rata-rata terendah sebesar 3,25 dengan kriteria baik pada indikator tingkat kemampuan agen asuransi dalam memahami apa yang didengar.

Dari evaluasi kemampuan intelektual di atas, dapat diambil kesimpulan jika semua indikator dari kemampuan intelektual telah diterapkan dengan baik maka kemampuan intelektual agen asuransi dapat lebih baik sehingga menciptakan kepuasan kerja agen.

\section{b. Promosi Jabatan Pada PT Prudential Life Assurance Cabang Pruaini Agency PS8 Pematangsiantar}

Berdasarkan dimensi yang digunakan dalam penelitian ini, hasil yang diperoleh dapat dijelaskan bahwa promosi jabatan yang diterapkan pada PT Prudential Life Assurance Cabang Pruaini PS8 Pematangsiantar dapat dikatakan baik, hal tersebut dapat dilihat dari hasil kuesioner yang diperoleh nilai rata-rata 3,68 berkriteria baik. Pada indikator melaporkan hasil kerja yang baik kepada atasan (leader) memperoleh nilai rata-rata 3,65 dengan kriteria jawaban baik, hal ini disebabkan sudah terujinya sistem kerja yang diterapkan oleh perusahaan untuk diikuti setiap agen perusahaan.Indikator loyalitas agen asuransi terhadap atasan (leader) berada pada rata-rata 3,62 dengan kriteria jawaban baik. Hal ini disebabkan karena fokusnya agen terhadap hasil yang akan dicapai bersama sehingga apapun yang menjadi rencana kerja 
atasan maka agen melaksanakannya dengan fokus pada hasil. Indikator syarat yang harus dilakukan dalam mempromosikan agen asuransi berada pada rata-rata 3,65 dengan kriteria jawaban baik. Hal ini disebabkan karena syarat untuk promosi tidak ditentukan karena tingkat pendidikan melainkan hasil kerja dan persistensi produksi yang dicapai agen asuransi.

Indikator perusahaan menentukan syarat promosi berdasarkan pengalaman kerja berada pada rata-rata 3,51 dengan kriteria jawaban baik. Hal ini disebabkan syarat mutlak untuk capai promosi jabatan adalah hasil pencapaian kerja agen itu sendiri tanpa melihat lamanya agen menguasai bidang asuransi sebagai pengalaman kerja. Pada dimensi inisiatif dengan indikator inisiatif agen asuransi dalam mencapai promosi berada pada ratarata 3,62 dengan kriteria jawaban baik. Hal ini disebabkan karena segala upaya untuk mencapai promosi sepenuhnya dari inisiatif agen itu sendiri. Indikator kreatif agen asuransi dalam mencapai promosi berada pada ratarata 3,60 dengan kriteria jawaban baik. Hal ini disebabkan karena agen dituntut lebih bisa kreatif dalam bekerja, lebih mandiri dalam mengelola waktu dan kesempatan. Indikator inovatif agen asuransi dalam mencapai promosi berada pada rata-rata 3,22 dengan kriteria jawaban baik. Hal ini disebabkan karena setiap agen asuransi memiliki inovasi tersendiri dalam menawarkan produk perusahaan sebagai bentuk komunikasi agen terhadap prospeknya.Secara keseluruhan dapat dilihat bahwa nilai rata-rata promosi jabatan yang dimiliki setiap agen asuransi berada pada nilai rata-rata 3,68 dengan kriteria jawaban baik sedangkan nilai rata-rata terendah sebesar 3,22 dengan indikator inovatif agen asuransi dalam mencapai promosi. Dari evaluasi promosi jabatan tersebut, dapat diambil kesimpulan jika semua indikator dari promosi jabatan telah diterapkan dengan baik maka promosi jabatan dapat tercapai sehingga dapat menciptakan kepuasan kerja agen asuransi.

\section{c. Kepuasan Kerja Agen Asuransi Pada PT Prudential Life Assurance Cabang Pruaini Agency PS8 Pematangsiantar}

Setiap agen asuransi memiliki tingkat kepuasan yang berbeda-beda tergantung dengan cara bagaimana agen asuransi menilainya, dan seorang agen akan merasa puas apabila kebutuhannya dapat terpenuhi. PT Prudential Life Assurance Cabang Pruaini Agency PS8 Pematangsiantar berusaha memberikan kepuasan kerja kepada setiap agennya agar tujuan perusahaan dapat tercapai. Berdasarkan dimensi yang digunakan dalam penelitian ini, hasil yang diperoleh dapat dijelaskan bahwa kepuasan kerja yang diterapkan pada PT Prudential Life Assurance Cabang Pruaini Agency PS8 Pematangsiantar dapat dikatakan baik, hal tersebut dapat dilihat dari hasil kuesioner yang diperoleh nilai ratarata 3,80 dengan kriteria baik.Pada dimensi kesempatan promosi dengan indikator kepuasan agen dengan pelatihan yang diberikan perusahaan dalam mengembangkan karir berada pada rata-rata 3,34 dengan kriteria jawaban cukup baik. Hal ini disebabkan karena setiap agen mendapatkan hak untuk mengikuti setiap pelatihan yang diadakan perusahaan sesuai dengan jabatannya. Indikator kepuasan agen terhadap perhatian sesama rekan kerja berada pada rata-rata 3,31 dengan kriteria jawaban cukup baik. Hal ini disebabkan karena tidak semua agen fokus akan hasil yang akan dicapai.

Selanjutnya pada indikator kepuasan agen dengan kemudahan yang diberikan perusahaan untuk bekerja dengan baik berada pada rata-rata 3,65 dengan kriteria jawaban baik. Hal ini disebabkan karena kemudahan agen dalam memproses berkas-berkas yang berhubungan dengan karir agen dipermudah perusahaan dengan adanya pendirian kantor cabang di daerah kota pematangsiantar.Secara keseluruhan dapat dilihat bahwa nilai rata-rata kepuasan kerja yang dimiliki setiap agen asuransi yang diberikan kepada responden berada pada nilai rata-rata 3,80 dengan kriteria jawaban baik sedangkan nilai rata-rata terendah sebesar 3,31 dengan kriteria baik pada indikator kepuasan agen asuransi terhadap perhatian sesama rekan kerja. Dari evaluasi kepuasan kerja tersebut, dapat diambil kesimpulan jika semua indikator kepuasan kerja agen telah terwujudkan dengan sangat baik maka akan mempercepat perwujudan tujuan/sasaran yang diinginkan perusahaan.

\section{KESIMPULAN DAN SARAN}

\section{Kesimpulan}

Dari seluruh uraian yang telah dikemukakan dalam bab sebelumnya, maka penulis menarik kesimpulan, yaitu sebagai berikut:

a. Hasil analisis deskriptif kualitatif kemampuan intelektual pada PT Prudential Life Assurance Cabang Pruaini Agency PS8 Pematangsiantar pada rata-rata 3,88 dengan kriteria jawaban baik. Nilai tertinggi pada indikator memori agen dalam mengingat suatu pekerjaan berada pada rata-rata 4,17 dengan kriteria jawaban baik, selanjutnya masih terdapat nilai terendah dengan indikator kemampuan agen dalam 
memahami apa yang didengar berada pada rata-rata 3,25 dengan kriteria jawaban cukup baik.

b. Hasil analisis deskriptif kualitatif promosi jabatan pada PT Prudential Life Assurance Cabang Pruaini Agency PS8 Pematangsiantar dari dimensi keseluruhan berada pada rata-rata 3,68 dengan kriteria jawaban baik. Indikator nilai tertinggi dari dimensi kejujuran pada Indikator melaksanakan penilaian prestasi kerja agen pada rata-rata 4,02 dengan kriteria jawaban baik. Selanjutnya, masih terdapat nilai terendah dengan indikator inovatifagen asuransi dalam mencapai promosi pada rata-rata 3,22 dengan kriteria jawaban baik.

c. Hasil analisis deskriptif kualitatif kepuasan kerja agen asuransi pada PT Prudential Life Assurance Cabang Pruaini Agency PS8 Pematangsiantar pada rata-rata 3,80 dengan kriteria jawaban puas. Indikator nilai tertinggi ada pada faktor yang mempengaruhi kesempatan promosi dengan indikator kepuasan agen terhadap kesempatan dalam bekerja dengan ratarata 3,97 dengan kriteria jawaban puas. Dan untuk indikator nilai terendah pada indikator kepuasan agen terhadap perhatian sesama rekan kerja pada rata-rata 3,31 dengan kriteria jawaban cukup baik.

d. Hasil analisis regresi yang diperoleh : $\hat{Y}=$ $10,850+0,494 X_{1}+0,418 X_{2}$ artinya terdapat pengaruh positif antara kemampuan intelektual dan promosi jabatan terhadap kepuasan kerja agen asuransi pada PT Prudential Life Assurance Cabang Pruaini Agency PS8 Pematangsiantar. Dengan diterapkannya kemampuan intelektual dan promosi jabatan dengan baik maka kepuasan kerja karyawan akan dapat tercapai.

e. Hasil analisis korelasi diperoleh nilai $r=$ 0,761 yang artinya terdapat hubungan yang kuat dan positif antara kemampuan intelektual dan promosi jabatan terhadap kepuasan kerja agen asuransi PT Prudential Life Assurance Cabang Pruaini Agency PS8 Pematangsiantar. Selanjutnya diperoleh koefisien determinasi $R=$ 0,579artinya tinggi rendahnya kepuasan kerja dapat dijelaskan sebesar $57,9 \%$ oleh kemampuan intelektual dan promosi jabatan, selebihnya $42,1 \%$ dijelaskan oleh faktor-faktor lain seperti kepemimpinan, motivasi, prestasi kerja, kompensasi, pengembangan karir dan faktor-faktor lain yang tidak dibahas dalam penelitian ini.

f. Hasil hipotesis dengan uji simultan diperoleh nilai $F_{\text {hitung }}$ sebesar 22,037 > Ftabel $(0,05: 2$ vs 32$)$ sebesar 3,29 atau dengan taraf signifikan $0,000<\alpha$ 0,05, maka $\mathrm{H}_{0}$ ditolak, artinya kemampuan intelektual dan promosi jabatan berpengaruh positif dan signifikan terhadap kepuasan kerja agen asuransi PT Prudential Life Assurance Cabang Pruaini Agency PS8 Pematangsiantar secara simultan.

g. Hasil hipotesis dengan uji parsial dilihat nilai thitung pada variabel kemampuan intelektual sebesar 3,167 >ttabel dengan df $=n-k-1$ ( $35-2-1=32$ ) sebesar 2,036 atau dengan taraf signifikan $0,003<\alpha 0,05$, maka $\mathrm{H}_{0}$ ditolak, artinya kemampuan intelektual berpengaruh positif dan signifikan terhadap kepuasan kerja agen asuransi pada PT Prudential Life Assurance Cabang Pruaini Agency PS8 Pematangsiantar. Kemudian nilai thitung pada veriabel promosi jabatan sebesar 2,441> tabel dengan $\mathrm{df}=\mathrm{n}-\mathrm{k}-1 \quad(35-2-1=32$ ) sebesar 2,036 atau dengan taraf signifikan $0,020<a 0,05$, maka $\mathrm{H}_{0}$ ditolak, artinya promosi jabatan berpengaruh positif dan signifikan terhadap kepuasan kerja agen asuransi pada PT Prudential Life Assurance Cabang Pruaini Agency PS8 Pematangsiantar.

\section{Saran}

Dari kesimpulan tersebut maka penulis mengutarakan beberapa saran untuk memecahkan masalah serta untuk mencapai tujuan yang telah ditetapkan yaitu:

a. Untuk lebih meningkatkan kemampuan intelektual agen asuransi PT Prudential Life Assurance Cabang Pruaini Agency PS8 Pematangsiantar sebaiknya agen asuransi lebih serius lagi mendengar dan memahami pelatihan, monday morning motivation (M3), business opportunity product (BOP) tentang asuransi dan memahami produk-produk baru asuransi.

b. Untuk lebih mengoptimalkan promosi jabatan agen asuransi PT Prudential life Assurance Cabang Pruaini Agency PS8 Pematangsiantar sebaiknya agen asuransi lebih serius lagi mengikuti seminar, pelatihan, menawarkan produk asuransi dengan berbagai inovasi sehingga calon nasaban tertarik untuk memiliki polis asuransi dengan demikian target produksi tercapai yang berdampak pada pengoptimalan kepuasan kerja agen asuransi.

c. Kepuasan kerja agen asuransi PT Prudential Life Assurance Cabang Pruaini Agency PS8 Pematangsiantar masih perlu ditingkatkan karena masih ada indikator yang belum optimal. Untuk mengoptimalkan kepuasan kerja agen asuransi, sebaiknya perusahaan lebih sering mengundang rekan kerja yang profesional, handal dan mempunyai dedikasi yang tinggi dalam menjalankan profesi agen asuransi sebagai sumber dukungan dan kenyamanan dalam menciptakan kepuasan kerja agen asuransi. 
d. Sehubungan dengan keterbatasan yang ada pada penulis, skripsi ini masih terdapat kelemahan dan belum dapat mengungkapkan seluruh variabel yang dapat mempengaruhi kepuasan kerja agen asuransi PT Prudential Life Assurance Cabang Pruaini Agency PS8 Pematangsiantar. Sebagai bahan masukan untuk penelitian selanjutnya, perlu memperbanyak variabel penelitian, seperti kepemimpinan, motivasi, prestasi kerja, kompensasi, pengembangan karir dan faktor-faktor lain yang tidak dibahas dalam skripsi ini.

\section{E. DAFTAR PUSTAKA}

Dessler, Gary. 2007. Manajemen Sumber Daya Manusia. Edisi 10, Jilid 1, Jakarta: Indeks.

Ghozali, Imam. 2013. Aplikasi Analisis Multivariate dengan Program SPSS. Semarang: Penerbit Universitas Diponegoro.

2007. Aplikasi Analisis Multivariate dengan Program SPSS. Semarang: Penerbit Universitas Diponegoro.

Griffin, Ricky W. 2004. Manajemen. Edisi VII,Jilid I. Jakarta: Erlangga.

Kreitner, Robert \& Angelo Kinicki. 2014. Perilaku Organisasi. Edisi 9. Buku 1. Jakarta: Salemba Empat.

Luthans, Fred. 2006. Perilaku Organisasi. Edisi Bahasa Indonesia. Yogyakarta: Andi.

Mangkuprawira, S. 2003. Manajemen Strategik. Bogor: Ghalia Indonesia.

Mathis, Robert $L$ dan John H. Jackson, 2006. Human Resources Management.Edisi Kesepuluh, Terjemahan Diana Angelica, Jakarta: Salemba Empat.

Mondy, Wayne. 2008. Manajemen Sumber Daya Manusia. Jakarta: Erlangga.

Nitisemito, Alex S. 2007. Manajemen Personalia. Cetakan Kesembilan, Edisi Ketiga, Penerbit Ghalia. Indonesia, Jakarta.

Robbins, Stephen, P. dan Timothy, Judge, A. 2009. Perilaku Organisasi. Buku 1, Edisi Kedua Belas. Jakarta: Salemba Empat.

Simbolon, Hotman. 2009. Statistika. Yogyakarta: Graha IImu.
Sugiyono, Dr. Prof. 2013. Metode Penelitian Kuantitatif, Kualitatif, Dan R\&D. Cetakan ke-19. Penerbit: Alfabeta Bandung.

Sutrisno, H. Edy. 2011. Manajemen Sumber Daya Manusia. Jakarta: Kencana.

Wahyudi, Bambang. 2002. Manajemen Sumber Daya Manusia. Bandung: Sulita. 